\title{
Planned Happenstance Skills as Personal Resources for Students' Psychological Wellbeing and Academic Adjustment
}

\author{
Andrius Valickas ${ }^{1}$, Agota Giedrè Raišienè ${ }^{1, *}$ and Violeta Rapuano ${ }^{2}$ \\ 1 Institute of Leadership and Strategic Management, Mykolas Romeris University, 20 Ateities str., Lithuania; \\ avalickas@mruni.eu \\ 2 Pellicceria Amica snc, Via Monte Genzana 14, 65124 Pescara, Italy; violeta.rapuano@amifur.com \\ * Correspondence: agotar@mruni.eu
}

Received: 15 May 2019; Accepted: 17 June 2019; Published: 20 June 2019

\begin{abstract}
Transition from the academic setting to the turbulent labour market requires more personal resources than ever before. In order to successfully enter and perform in professional life one must be ready to respond adequately to conditions of uncertainty and complexity. The concept of planned happenstance skills presents a set of competencies to deal effectively with unplanned events generated by chaotic environment. These career-related resources are extremely important for students pursuing successful adaption to professional environments and seeking to prepare for personal career management. The present article aims to analyze the role of planned happenstance skills when predicting psychological wellbeing and academic adjustment. Lithuania was chosen as a case study since there is a high percentage of people with higher education. The study was conducted using the quantitative method of questionnaire survey. Data of the survey were analyzed using correlation and multiple regression analyses. It was found that planned happenstance skills had a significant positive relationship with study variables and were a significant predictor of academic achievement and psychological wellbeing.
\end{abstract}

Keywords: planned happenstance; psychological wellbeing; career management; academic adjustment; sustainable development for well-being

\section{Introduction}

In the contemporary world of work, an individual seeking to pursue a successful and meaningful career must adapt to a variety of continuous changes and complex environments. Unpredictable events are an important component influencing individual career development [1]. However, traditional career counselling theories (person-profession fit theories) have focused on the control process rather than trying to include the concept of change in career counselling, which is usually considered to be a service provided for students by higher education institutions. Nowadays, possessing a set of professional competencies may no longer be sufficient for successful career development, additional resources are needed in order to flourish in the turbulent labour market [2]. The theory of planned happenstance [3-5] is a comprehensive framework offering an explanation and solution of how to manage a career in conditions of unpredictability and to benefit from unexpected events. The role of chance events in an individual career has been proven by various empirical studies [6-10]. According to authors [1-11], unpredictable events can turn into learning experience which leads to positive consequences in career development. Furthermore, pursuant to the concept of planned happenstance, there is a set of skills which enable individuals to recognize, create and use unplanned events as their career opportunities. These competencies are particularly important to students since apart from 
developing their professional qualifications, they should also seek to acquire the resources which facilitate a successful adaptation to the academic environment, and even more, to prepare for their career management in this rapidly changing world. In addition, gaining career-related resources stimulates positive outcomes already while studying which can create a good basement for starting off students' careers with strong human and psychological capital [2]. The planned happenstance skills help survival and ensure success in the contemporary world of work, the issues which higher education institutions are preparing students for. In recent years there has been growing interest in the concept's relationship with other career-related variables. Planned happenstance skills have been found to be associated with occupational engagement, career decision self-efficacy [12,13], intrinsic work values, career networking [5], life adjustment [4], career decision self-efficacy and decrease in dysfunctional career thoughts [14]. The utilization of planned happenstance skills may not only be beneficial with regard to career-related challenges but also to managing students' daily life issues.

Psychological wellbeing and quality of life of human beings is central to psychology of sustainable development and sustainability. With reference to Di Fabio [15], psychological wellbeing can be achieved by building resources and strengths, thus preventing negative outcomes in the future. Utilizing planned happenstance skills may be perceived as a preventive individual strength which helps to cope with the challenges posed by the turbulent reality of 21st century. In other words, having resources and knowledge of positive functioning in today's modern society may be a great facilitator for individuals to create and lead meaningful lives and careers and, in general, to promote their wellbeing in different contexts and environments. Hence, we believe planned happenstance skills may stimulate students' psychological wellbeing and an easier adjustment to academic settings. However, too little attention has been paid to comprehensive investigation into the relationship of planned happenstance skills with psychological wellbeing and with academic adjustment.

The aim of the present study is to examine whether planned happenstance skills affect psychological wellbeing and academic adjustment.

The paper consists of five parts. Section 2, i.e., the literature analysis section, provides a brief theoretical overview of the happenstance learning theory and explains the conception of planned happenstance skills, together with formulating the hypothesis of the research. The methodology of the research is outlined in Section 2. In Section 2, analysis results are examined, and conclusions are drawn in the final part.

\section{Materials and Methods}

\subsection{Planned Happenstance Concept}

Career management, as the process of only making rational decisions based on logics is increasingly becoming difficult to perceive in the modern world. Many researchers agree upon the existence of chance events in career path, thus almost nobody tried to integrate them in the career decision making process [1]. The concept of planned happenstance, first introduced by Mitchell et al. [1], treats unplanned events as "inevitable and desirable" in everyone's career. Interpreting the existence of chance events within a career, we may resort to the chaos theory of careers which explains the mechanism of individual adaptation to modern changes [16]. This theory treats an individual as a complex dynamic system being in a constant interaction with other systems of this kind (employers, labour market, national and global economy, etc.). The interaction of these systems creates, at one time or another, events unplanned beforehand since an individual is a limited creature disposing of a limited quantity of information and as a result, the complete career control becomes impossible [16]. Therefore, chance events should be considered as a normal phenomenon in every individual's career and life in general [17]. Likewise, the results of empirical studies confirm the importance of chance events to an individual's personal career. In accordance with the research data [6-9], more than half of the respondents participating in various research $(60 \%, 65 \%, 69 \%, 82 \%$ respectively) have indicated that unplanned, chance events had an impact on their careers or career decisions. The planned happenstance 
theory [1] or otherwise the happenstance learning theory [3,18], unlike other career counselling theories eliminating the existence of unplanned events in a person's career path, treats such events as a learning experience which may turn into useful career opportunities. In accordance with this theory, chance events are inevitable and even desired [19]. The key idea behind the happenstance learning theory is that one should adopt an active position in identifying and generating, by himself/herself, planned happenstance events which may be utilised as career opportunities. It is advisable to not only transform these events into favourable career opportunities but also to generate planned events by oneself.

The planned happenstance theory suggests the guidelines for taking constructive action in order to create beneficial opportunities in career development [12-20]. To begin with, the theory places an emphasis on exploratory activities [21]. Career exploration is seen as a means of creating chance opportunities. According Krumboltz et al. [3] individuals should learn to engage in exploratory activity rather than merely talking about their desires since creating success experiences which increase individual's self-efficacy can increase the range of activities an individual sees as possible. Secondly, Mitchell et al. [1] maintain that there is set of skills which enables people to seize opportunities efficiently. The five skills for planned happenstance are as follows: curiosity (refers to "exploring new learning opportunities"), persistence (refers to "exerting effort despite setbacks"), flexibility (referring to "changing attitudes and circumstances"), optimism (making reference to "viewing new opportunities as possible and attainable") and risk taking (refers to "taking action in the face of uncertain outcomes") [1]. These skills help recognise, create and use chance events as career opportunities [22].

\subsection{Planned Happenstance and Wellbeing}

Krumboltz [18] points out that one's career and personal life are intertwined. From the point of view of the planned happenstance theory, taking advantage of chance events may contribute to building more satisfying personal and professional lives $[3,18]$. Career is a crucial element in one's life and has an impact on an individual's welfare. This proposition has been supported by empirical researches indicating a close relationship between career satisfaction and wellbeing [23-25]. The happenstance learning theory holds that there should not be a distinction between career and personal counselling inasmuch as our career affects our personal life and vice versa. The theory suggests adopting a positive attitude towards the uncertainty and unpredictability of the contemporary world. It calls us to consider unpredictable events as possible career opportunities rather than unsettling occurrences. Gaining the competencies of planned happenstance is of the utmost importance for students who are about to enter the labour market and to pursue successful careers. The concept of planned happenstance skills encourages an individual to take an active position in creating a satisfactory life, while at the same time accepting the complexity of life and making use of unplanned events generated by this complexity. The notion of being able to act successfully in turbulent environments and to cope with unpredictable events can influence an individual's welfare. Hence, we expect that the utilization of planned happenstance skills may contribute to students' psychological wellbeing. Wellbeing is usually as life satisfaction, absence of negative emotions, optimism, and positive emotions [26]. The term refers to self-reported happiness and satisfaction with specific domains and activities in life. Previous studies have shown wellbeing to be associated with personality traits like optimism [27] and the sense of personal control [28]. As proposed by Myers and Diener [29], the individuals who feel empowered, rather than helpless, cope better with daily challenges and are typically happier. In a similar vein, planned happenstance skills include optimism and an active behaviour in overcoming obstacles and constructing beneficial chance events. There are only a few studies where planned happenstance skills' relationship with the similar constructs to wellbeing are investigated. The results of those studies indicate the importance of the planned happenstance skills for the higher level of career satisfaction [30] and life adjustment [4]. Accordingly, we aim to investigate how the skills of planned happenstance are related to psychological wellbeing and its multiple facets including autonomy, environmental mastery, personal growth, positive relations, purpose in life and self-acceptance. 
Thus, with reference to what has been set forth above and findings from earlier empirical works, the following hypothesis may be put forward:

H1: Planned happenstance skills predict students' psychological wellbeing.

\subsection{Planned Happenstance and Academic Adjustment}

Adaptability has become one of the most important individual competences helping to flourish in the contemporary fluid and ambiguous environment [31]. Adaptability may briefly be described as the capacity to respond to challenges with resilience [32]. Previous studies have demonstrated the role of adaptability in a successful career development [33]. The concept refers to an individual's ability/skill and/or motivation to fit changing demands (different tasks, social or environmental features) [34]. In other words, adaptability is the capacity of being able to adjust to new conditions. In this paper we have chosen to investigate students' adaptation to academic settings, named academic adjustment. Adjustment to college is perceived to be a process of transition during which students face several challenges, including greater academic demands, autonomy and responsibilities as compared with their high school experiences [35]. The concept is multidimensional and assesses students' success in coping with various academic demands such as academic achievement, motivation, academic lifestyle [36]. According to Krumboltz et al. [3], a creative adjustment to changing environments and new opportunities is one of the key tasks career counsellors should teach their students. The capability to cope with sudden changes and instability is a crucial skill for students to gain before entering a complex labour market. The use of planned happenstance skills may not only be beneficial with regard to career-related challenges but also to managing students' daily life issues. Hence, the utilisation of planned happenstance skills is expected to contribute to successful tackling the challenges related to new situations which, as a result, lead to an easier adaption to new professional (academic) environments. Recently, Kim et al. [4] has found that planned happenstance skills preceded and were positively related to life adjustment. However, it is not yet clear if the empirical relationship between planned happenstance skills and academic adjustment exists.

Accordingly, we offer the following hypothesis:

H2: Planned happenstance skills predict students' academic adjustment.

\subsection{Participants and Procedure}

Students from two higher education institutions in Lithuania participated in this study. The sample consisted of students awarding Bachelor's (56\%) and Master's (49\%) degree in Business and Management. In terms of gender distribution (Table 1), $72.4 \%$ of the participants were female $(\mathrm{N}=76)$ and $27.6 \%$ were male $(\mathrm{N}=29)$. Their age ranged from 18 to 48 years $(\mathrm{M}=25.6, \mathrm{SD}=7.458)$. Such extensive variety of respondents' ages enabled us to investigate the problem in common context of studying individuals. Data collection took place from November 2018 to February 2019. Data were collected via web-based survey which took approximately $15 \mathrm{~min}$ on average to complete. The data collected was stored in data files and later downloaded into SPSS statistical software for analysis. All participants were informed about the purpose of the study. Participation was voluntary, and the respondents were assured of the confidentiality of their response. The participants were not paid for participation. 
Table 1. Socio-demographic characteristics.

\begin{tabular}{|c|c|c|c|}
\hline \multicolumn{2}{|c|}{ Variable } & \multirow{3}{*}{$\begin{array}{l}\mathbf{N} \\
76 \\
29\end{array}$} & \multirow{3}{*}{$\begin{array}{c}\text { \% } \\
72.4 \\
27.6\end{array}$} \\
\hline & Female & & \\
\hline Gender & Male & & \\
\hline \multirow{4}{*}{ Age } & 18-19 & 27 & 25.7 \\
\hline & $20-23$ & 28 & 26.7 \\
\hline & $24-30$ & 26 & 24.7 \\
\hline & $31-48$ & 24 & 22.9 \\
\hline \multirow{2}{*}{ Academic Degree } & Bachelor & 56 & 53.3 \\
\hline & Master & 49 & 46.7 \\
\hline Total & & 105 & 100 \\
\hline
\end{tabular}

\subsection{Instruments}

Planned happenstance skills. Planned Happenstance Career Inventory (PHCI) [12] consists of 25 items divided equally into five subscales that assess planned happenstance resources: curiosity (e.g., "I tend to be curious about unexpected events"), persistence (e.g., "I would persist in my efforts despite any unexpected barriers"), flexibility (e.g., "I think that my career could change at any point in my life"), optimism (e.g., "I have a positive view of my future career), and risk-taking (e.g., "I am willing to take risks despite the consequences being uncertain"). The total score provided an overall measure for planned happenstance. All items were positively worded and rated using a 5-point Likert-type scale ranging from 1 (I do not agree at all) to 5 (I strongly agree). All items were averaged. Total scores were calculated by averaging the responses of each subscale. Higher scores indicated a greater likelihood of using the five skills. In this study, the reliability coefficient of the overall scale was 0.82 and the respective Cronbach's $\alpha$ s for curiosity, persistence, flexibility, optimism, and risk were $0.644,0.810$, $0.721,0.891,0.709$.

Academic adjustment. We used the Academic Adjustment Scale (AAS) [36] which was developed to measure the adjustment of permanent resident or sojourner students. We used two subscales: academic achievement (e.g., "I am satisfied with the level of my academic performance to date") and academic motivation (e.g., "The reason I am studying is to lead to a better lifestyle"). The items were scored on 5-point Likert-type scale ( $1=$ "Rarely applies to me" to $5=$ "Always applies to me"). Higher scores indicated better academic adjustment. Reliability coefficients (Cronbach's $\alpha$ ) were 0.85 for academic achievement and 0.50 for academic motivation. Since Cronbach $\alpha$ for academic motivation was too low, we removed one item ("I expect to successfully complete my degree in the usual allocated timeframe"). The new subscale consisted of two items and internal consistency was 0.63 .

Psychological well-being. It was assessed using Ryff's Psychological Well-Being Scale (PWB) $[37,38]$. It is a 42-item scale measuring psychological well-being. The scale was divided into six subscales: autonomy (e.g., "I judge myself by what I think is important, not by the values of what others think is important"), environmental mastery (e.g., "I have been able to build a home and a lifestyle for myself that is much to my liking"), personal growth (e.g., "For me. life has been a continuous process of learning, changing and growth"), positive relations (e.g., "I know that I can trust my friends, and they know they can trust me"), purpose in life (e.g., "Some people wander aimlessly through life, but I am not one of them") and self-acceptance (e.g., "I like most aspects of my personality"). There are items for each subscale, being rated on a 6-point Likert-type scale from 1 (Strongly disagree) to 6 (Strongly agree) and 20 of the 42 were coded reversely. Higher scores indicated greater levels of the subscale. The Cronbach $\alpha$ s for subscales were $0.71,0.78,0.77,0.78,0.84,0.84$, respectively, and for the total scale it was 0.94 . 


\section{Results and Discussion}

Mean items scores (Table 2) for the study variables were in the high range indicating that students' level of planned happenstance skills, psychological well-being and academic adjustment were high enough. Specifically, the data indicated that students were characterized by high levels of optimism $(M=19.96 ; S D=3.571)$, flexibility $(M=20.64 ; S D=2.743)$, curiosity $(M=20.57 ; S D=2.353)$. and personal growth $(\mathrm{M}=28.63 ; \mathrm{SD}=3.776)$.

Table 2. Means and standard deviations of study variables.

\begin{tabular}{ccc}
\hline Construct & Mean & Standard Deviation \\
\hline Optimism & 19.96 & 3.571 \\
Flexibility & 20.64 & 2.743 \\
Persistence & 18.50 & 2.942 \\
Curiosity & 20.57 & 2.353 \\
Risk Taking & 15.54 & 2.094 \\
Autonomy & 25.87 & 3.991 \\
Environmental Mastery & 25.25 & 3.978 \\
Personal Growth & 28.63 & 3.776 \\
Positive Relations & 27.27 & 4.606 \\
Purpose in Life & 26.81 & 4.530 \\
Self-acceptance & 25.40 & 4.718 \\
Academic Achievement & 10.86 & 2.412 \\
Academic Motivation & 7.70 & 1.737 \\
\hline
\end{tabular}

Source: Authors' results.

As can be seen in Table 3, correlations indicated significant relationship between overall planned happenstance score and overall psychological well-being score $(r=0.525 . p<0.01)$. Furthermore. overall planned happenstance score was found to be significantly related to all the dimensions of psychological well-being indicating that the more students utilize the planned happenstance skills the better they feel about their autonomy $(\mathrm{r}=0.354 . p<0.01)$, environmental mastery $(\mathrm{r}=0.487 . p<0.01)$, personal growth $(\mathrm{r}=0.562 . p<0.01)$, positive relations $(\mathrm{r}=0.358 . p<0.01)$, purpose in life $(\mathrm{r}=0.368$. $p<0.01)$ and self-acceptance $(\mathrm{r}=0.549 . p<0.01)$. The planned happenstance dimension of optimism was significantly and positively associated to all psychological well-being dimensions (correlations ranging from $r=0.334 . p<0.01$ to $r=0.453 . p<0.01$ ). Other dimensions of flexibility, persistence, curiosity and risk taking were significantly correlated with most of planned happenstance dimensions, whereas the strongest relations were found between flexibility and self-acceptance $(r=0.344 . p<0.01)$, risk taking and personal growth $(r=0.367 . p<0.01)$.

Table 3. Correlation between study variables.

\begin{tabular}{|c|c|c|c|c|c|c|}
\hline Construct & $\begin{array}{l}\text { Overall Planned } \\
\text { Happenstance }\end{array}$ & Optimism & Flexibility & Persistence & Curiosity & Risk Taking \\
\hline $\begin{array}{l}\text { Overall psychological } \\
\text { well-being }\end{array}$ & $0.525^{* *}$ & $0.495^{* *}$ & $0.237 *$ & $0.303^{* *}$ & $0.224^{*}$ & $0.264 * *$ \\
\hline Autonomy & $0.354^{* *}$ & $0.334^{* *}$ & 0.158 & $0.295^{* *}$ & 0.091 & $0.211 *$ \\
\hline Environmental Mastery & $0.487^{* *}$ & $0.453 * *$ & $0.280 * *$ & $0.252 * *$ & $0.219 *$ & $0.212 *$ \\
\hline Personal Growth & $0.562 * *$ & $0.429 * *$ & $0.268 * *$ & $0.276^{* *}$ & $0.303 * *$ & $0.367 * *$ \\
\hline Positive Relations & $0.358 * *$ & $0.338 * *$ & 0.234 ** & 0.142 & 0.107 & 0.107 \\
\hline Purpose in Life & $0.368 * *$ & $0.369 * *$ & 0.048 & $0.282 * *$ & 0.119 & $0.238 *$ \\
\hline Self-acceptance & $0.549 * *$ & $0.449 * *$ & $0.344^{* *}$ & $0.289 * *$ & $0.298 * *$ & $0.206^{*}$ \\
\hline Academic achievement & $0.479 * *$ & $0.437^{* *}$ & $0.272 * *$ & $0.238^{*}$ & $0.322 * *$ & 0.158 \\
\hline Academic motivation & 0.026 & -0.021 & -0.125 & $0.204^{*}$ & 0.120 & -0.021 \\
\hline
\end{tabular}


Next, we checked the relationship between planned happenstance skills and dimensions of academic adjustment (Table 3). It appeared that planned happenstance skills had a significant relationship with academic achievement $(\mathrm{r}=0.479 . p<0.01)$. More specifically all planned happenstance resources were correlated with academic achievement except for risk taking. Unfortunately, overall planned happenstance score does not show significant correlation with academic motivation. Persistence was the only dimension found to be associated to academic motivation $(r=0.204$. $p<0.05)$.

To examine the predictive role of planned happenstance skills on psychological well-being, multiple regression analysis was conducted. The results (Table 4) of the regression indicated one predictor explained $31.5 \%(\mathrm{~F}(5.99)=10.565 . p<0.0001)$ of variance. More specifically, optimism significantly predicted psychological well-being $(\beta=0.456 . p<0.001)$. Thus, we found support for hypothesis 1 indicating the importance of planned happenstance skills in predicting psychological well-being.

Table 4. Multiple Regression Analysis Predicting Psychological Well-being.

\begin{tabular}{ccccc}
\hline Predictor & $\boldsymbol{\beta}$ & $\boldsymbol{p}$ & $\boldsymbol{t}$ & $\boldsymbol{R}^{\mathbf{2}} \boldsymbol{a d j}$ \\
\hline Optimism & 0.456 & $p<0.001$ & 5.138 & \\
Flexibility & 0.145 & 0.113 & 1.598 & \\
Persistence & 0.166 & 0.084 & 1.746 & 0.315 \\
Curiosity & 0.072 & 0.427 & 0.798 & \\
Risk taking & -0.007 & 0.940 & -0.076 & \\
\hline
\end{tabular}

Source: Authors' results. $\beta$-estimated value of standardized regression coefficient (Beta); $R^{2} a d j$-adjusted $\mathrm{R}$ squared (coefficient of determination); $p$ — significance level.

Next, we checked the predictive role of planned happenstance skills on academic achievement (Table 5) and academic motivation (Table 6). It appeared that two predictors explained 26.7\% $(\mathrm{F}(5.99)=8.560)$ of academic achievement variance where specifically optimism and flexibility showed significant standardized regression coefficients $(\beta=0.406 . p<0.001 ; \beta=0.188 . p<0.05)$. It is important to note that optimism was a stronger predictor of academic achievement than flexibility.

Table 5. Multiple Regression Analysis Predicting Academic Achievement.

\begin{tabular}{ccccc}
\hline Predictor & $\boldsymbol{\beta}$ & $\boldsymbol{p}$ & $\boldsymbol{t}$ & $\boldsymbol{R}^{\mathbf{2}}$ adj \\
\hline Optimism & 0.406 & $p<0.001$ & 4.414 & \\
Flexibility & 0.188 & $p<0.05$ & 2.011 & \\
Persistence & 0.139 & 0.161 & 1.411 & 0.267 \\
Curiosity & 0.133 & 0.159 & 1.419 & \\
Risk taking & -0.101 & 0.291 & -1.061 & \\
\hline
\end{tabular}

Source: Authors' results. $\beta$-estimated value of standardized regression coefficient (Beta); $R^{2}$ adj—adjusted $\mathrm{R}$ squared (coefficient of determination); $p$ —significance level.

Table 6. Multiple Regression Analysis Predicting Academic Motivation.

\begin{tabular}{ccccc}
\hline Predictor & $\boldsymbol{\beta}$ & $\boldsymbol{p}$ & $\boldsymbol{t}$ & $\boldsymbol{R}^{\mathbf{2}}$ adj \\
\hline Persistence & 0.057 & $p<0.05$ & 2.079 & 0.031 \\
\hline
\end{tabular}

Source: Authors' results. $\beta$-estimated value of standardized regression coefficient (Beta); $R^{2}$ adj —adjusted $\mathrm{R}$ squared (coefficient of determination); $p$ — significance level.

To examine the predictors of academic motivation we included only persistence as a possible predictor since only this planned happenstance dimension was significantly correlated to the factor variable. Persistence accounted for $4 \%(F(1.103)=4.320 . p<0.05)$ of academic motivation variance. Overall, these findings provide a support for Hypothesis 2.

We also tested the predictive role of planned happenstance skills on the dimensions of psychological well-being. To decrease the amount of variance explained by non-significant correlates, we included 
only the variables significantly related to factor variables. The findings indicated (Tables 7-12) that planned happenstance skills significantly (respectively $\mathrm{F}(3.101)=4.749 . p<0.005 ; \mathrm{F}(5.99)=8.244$. $p<0.0001 ; \mathrm{F}(5.99)=9.335 . p<0.0001 ; \mathrm{F}(2.102)=10.964 . p<0.0001 ; \mathrm{F}(3.101)=10.824 . p<0.0001$; $\mathrm{F}(4.100)=12.656 . p<0.0001)$ accounted for all the dimensions of psychological well-being where the standardized regression coefficients ranged from $\beta=0.124$ to $\beta=0.336$.

Table 7. Multiple Regression Analysis Predicting Autonomy.

\begin{tabular}{ccccc}
\hline Predictor & $\boldsymbol{\beta}$ & $\boldsymbol{p}$ & $\boldsymbol{t}$ & $\boldsymbol{R}^{2}$ adj \\
\hline Optimism & 0.273 & $p<0.01$ & 2.727 & \\
Persistence & 0.068 & 0.525 & 0.638 & 0.098 \\
Risk taking & 0.119 & 0.239 & 1.185 & \\
\hline
\end{tabular}

Source: Authors' results. $\beta$-estimated value of standardized regression coefficient (Beta); $R^{2} a d j$-adjusted $\mathrm{R}$ squared (coefficient of determination); $p$ —significance level.

Table 8. Multiple Regression Analysis Predicting Environmental Mastery.

\begin{tabular}{ccccc}
\hline Predictor & $\boldsymbol{\beta}$ & $\boldsymbol{p}$ & $\boldsymbol{t}$ & $\boldsymbol{R}^{2}$ adj \\
\hline Optimism & 0.396 & $p<0.001$ & 4.281 & \\
Flexibility & 0.194 & $p<0.05$ & 2.053 & \\
Persistence & 0.162 & 0.104 & 1.639 & 0.258 \\
Curiosity & 0.061 & 0.520 & 0.646 & \\
Risk taking & -0.033 & 0.729 & 0.729 & \\
\hline
\end{tabular}

Source: Authors' results. $\beta$-estimated value of standardized regression coefficient (Beta); $R^{2} a d j$ —adjusted $\mathrm{R}$ squared (coefficient of determination); $p$-significance level.

Table 9. Multiple Regression Analysis Predicting Personal Growth.

\begin{tabular}{ccccc}
\hline Predictor & $\boldsymbol{\beta}$ & $\boldsymbol{p}$ & $\boldsymbol{t}$ & $\boldsymbol{R}^{2}$ adj \\
\hline Optimism & 0.331 & $p<0.001$ & 3.651 & \\
Flexibility & 0.165 & 0.078 & 1.781 & \\
Persistence & 0.066 & 0.498 & 0.679 & 0.286 \\
Curiosity & 0.155 & 0.097 & 1.676 & \\
Risk taking & 0.184 & 0.052 & 1.970 & \\
\hline
\end{tabular}

Source: Authors' results. $\beta$-estimated value of standardized regression coefficient (Beta); $R^{2} a d j$-adjusted $\mathrm{R}$ squared (coefficient of determination); $p$-significance level.

Table 10. Multiple Regression Analysis Predicting Positive Relations.

\begin{tabular}{ccccc}
\hline Predictor & $\boldsymbol{\beta}$ & $\boldsymbol{p}$ & $\boldsymbol{t}$ & $\boldsymbol{R}^{2}$ adj \\
\hline Optimism & 0.377 & $p<0.001$ & 4.149 & \\
Flexibility & 0.139 & 0.129 & 1.529 & 0.161
\end{tabular}

Source: Authors' results. $\beta$-estimated value of standardized regression coefficient (Beta); $R^{2} a d j$-adjusted $\mathrm{R}$ squared (coefficient of determination); $p-\mathrm{N}=105$.

Table 11. Multiple Regression Analysis Predicting Purpose in Life.

\begin{tabular}{ccccc}
\hline Predictor & $\boldsymbol{\beta}$ & $\boldsymbol{p}$ & $\boldsymbol{t}$ & $\boldsymbol{R}^{2}$ adj \\
\hline Optimism & 0.411 & $p<0.001$ & 4.421 & \\
Persistence & 0.173 & 0.081 & 1.762 & 0.221 \\
Risk Taking & -0.32 & 0.731 & -0.344 &
\end{tabular}

Source: Authors' results. $\beta$-estimated value of standardized regression coefficient (Beta); $R^{2} a d j$-adjusted $\mathrm{R}$ squared (coefficient of determination); $p-\mathrm{N}=105$.

The results of regressions revealed that predictive role of planned happenstance skills is the highest when predicting environmental mastery $\left(R^{2}=0.258 . p<0.0001\right)$, personal growth $\left(R^{2}=0.286\right.$. $p<0.0001)$, purpose in life $\left(R^{2}=0.221 . p<0.0001\right)$ and self-acceptance $\left(R^{2}=0.310 . p<0.0001\right)$ as the accounted variance for autonomy (Table 6 ) and positive relations (Table 9 ) is lower than $20 \%$. Optimism 
presented significant standardized regression coefficient for all psychological well-being dimensions whereas flexibility was significant predictor of environmental mastery and self-acceptance.

Table 12. Multiple Regression Analysis Predicting Self-acceptance.

\begin{tabular}{ccccc}
\hline Predictor & $\boldsymbol{\beta}$ & $\boldsymbol{p}$ & $\boldsymbol{t}$ & $\boldsymbol{R}^{\mathbf{2}}$ adj \\
\hline Optimism & 0.425 & $p<0.001$ & 4.759 & \\
Flexibility & 0.220 & $p<0.05$ & 2.449 & \\
Persistence & 0.137 & 0.131 & 1.522 & 0.310 \\
Curiosity & 0.067 & 0.451 & 0.757 & \\
\hline
\end{tabular}

Source: Authors' results. $\beta$-estimated value of standardized regression coefficient (Beta); $R^{2} a d j$-adjusted $\mathrm{R}$ squared (coefficient of determination); $p-\mathrm{N}=105$.

Summarizing. data analysis revealed that planned happenstance skills are significant predictor of students' psychological well-being and academic adjustment. Specifically, optimism was found to play an important role in predicting academic achievement and all aspect of psychological well-being. Thus, in line with our expectations planned happenstance skills might serve as an important personal resource stimulating students' well-being and successful adaptation to new professional environments.

\section{Conclusions}

Our study has several important implications. Firstly, this study adds empirical evidence and strengthens the theory of the planned happenstance which, despite the growing research interest, receives little empirically based findings. In line with our expectations, the results of the study revealed that all planned happenstance skills were positively related to psychological well-being and most of its facets. Furthermore, the planned happenstance skill optimism was a significant predictor of well-being. Current research extended the existing studies by showing that planned happenstance skills predicted not only career-related variables but also psychological variables. We stated that the skills of planned happenstance can serve as important personal resources stimulating students' welfare through adopting a positive attitude towards uncertainty and unpredictable events. Consistent with our expectations, the findings revealed that optimism as a dimension of planned happenstance was an important predictor of the aspects of well-being such as environmental mastery, personal growth, and self-acceptance, indicating that optimistic view on future career opportunities and attainability play a significant role in attaining a higher level of mastery and competence in managing the environment, feelings of continued development, and possessing a positive attitude toward the self. Also, flexibility (ability to change attitudes and cope with changing circumstances) was found to be a significant predictor of environmental mastery and self-acceptance. Thus, career related optimism and flexibility, which predict psychological wellbeing, can be perceived as significant individual strengths which contribute to sustainable development of each person in different contexts.

Taking into consideration the research findings, institutions of higher education in the process of developing professional and employability competencies of the students should pay more attention to planned happenstance skills enabling students to constructively deal with complex situations, to maintain professional mastery and personal growth tendencies after graduation. This is especially relevant in the context of permanent changes in the labor market, which require the participants in it to sustain their employability and assure their wellbeing via personal resources.

The test results of the second hypothesis revealed mixed findings. The planned happenstance skills were significantly related to and predicted students' academic achievement, a component of academic adjustment. Thus, our results confirmed the theoretical notion that utilizing the skills of planned happenstance prompts positive, active behavior and contributes to a productive adaption to new environments. However, the planned happenstance skills were not related to academic motivation except for the persistence dimension.

The present study gives certain insights to future research. First, the data of the study were cross-sectional. Although the planned happenstance skills predicted psychological wellbeing and 
academic adjustment in our study, the causality is not clear between variables. Thus, future longitudinal studies should measure variables over time. Second, we used only self-reported questionnaires. Future researchers should consider using multiple assessment methods to measure the constructs. Besides subjective measuring of academic achievement, an objective method such as GPA scores could be used. Finally, as a person's psychological wellbeing in general is integral with the sustainability of organizations and the sustainability of the society [39-41], it is important to explore the planned happenstance phenomenon in a broader context.

Author Contributions: All authors contributed equally to this paper.

Funding: This research received no external funding.

Conflicts of Interest: The authors declare no conflict of interest.

\section{References}

1. Mitchel, K.E.; Levin, S.A.; Krumboltz, J.D. Planned happenstance: Constructing unexpected career opportunities. J. Couns. Dev. 1999, 77, 115-124. [CrossRef]

2. Akkermans, J.; Paradnike, K.; Van der Heijden, B.I.J.M.; De Vos, A. The Best of Both Worlds: The Role of Career Adaptability and Career Competencies in Students' Well-Being and Performance. Front. Psychol. 2018, 9, 1678. [CrossRef] [PubMed]

3. Krumboltz, J.D.; Foley, P.F.; Cotter, E.W. Applying the Happenstance Learning Theory to Involuntary Career Transitions. Career Dev. Q. 2013, 61, 15-26. [CrossRef]

4. Kim, B.; Kim, S.R.; Yang, N.Y.; Ha, G.Y.; Yang, J.Y.; Lee, B.; Lee, S.M. Longitudinal Relationships between Planned Happenstance Skills and Life Adjustment and the Moderating Role of Career Barriers. J. Career Dev. 2018, 45, 215-226. [CrossRef]

5. Eissenstat, S.J.; Nadermann, K. Examining the Use of Planned Happenstance with Students of Korean Cultural Backgrounds in the United States. J. Career Dev. 2018, 1-14. [CrossRef]

6. Betsworth, D.G.; Hanson, J.C. The Categorization of Serendipitous Career Development Events. J. Career Assess. 1996, 4, 91-98. [CrossRef]

7. Hirschi, A. The role of chance events in the school-to-work transition: The influence of demographic. personality and career development variables. J. Vocat. Behav. 2010, 77, 39-49. [CrossRef]

8. Bright, J.E.H.; Pryor, R.G.L.; Harpham, L. The Role of Chance Events in Career Decision Making. J. Vocat. Behav. 2005, 66, 561-576. [CrossRef]

9. Bright, J.E.H.; Pryor, R.G.L.; Chan, E.; Rijanto, E.J. The Dimensions of Chance Career Episodes. J. Vocat. Behav. 2009, 75, 14-25. [CrossRef]

10. Hordósy, R.; Clark, T. 'It's Scary and It's Big. and There's No Job Security': Undergraduate Experiences of Career Planning and Stratification in an English Red Brick University. Soc. Sci. 2018, 7, 173.

11. Kim, N.; Jang, S.Y.; Baek, P. Career chance experience of Korean women workers. Career Dev. Int. 2019, 24, 74-90. [CrossRef]

12. Kim, B.; Jung, S.H.; Jang, S.H.; Lee, B.H.; Rhee, E.; Cho, S.H.; Lee, S.M. Construction and initial validation of the planned happenstance career inventory. Career Dev. Q. 2014, 62, 239-253. [CrossRef]

13. Kindsiko, E.; Baruch, Y. Careers of Ph.D. graduates: The role of chance events and how to manage them. J. Vocat. Behav. 2019, 112, 122-140. [CrossRef]

14. Kim, B.; Lee, B.H.; Ha, G.; Lee, H.K.; Lee, S.M. Examining Longitudinal Relationships between Dysfunctional Career Thoughts and Career Decision-Making Self-Efficacy in School-to-Work Transition. J. Career Dev. 2015, 42, 511-523. [CrossRef]

15. Di Fabio, A. The Psychology of Sustainability and Sustainable Development for Well-Being in Organizations. Front. Psychol. 2017, 8, 1534. [CrossRef] [PubMed]

16. Pryor, R.G.L.; Bright, J.E.H. Applying chaos theory to careers: Attraction and attractors. J. Vocat. Behav. 2007, 71, 375-400. [CrossRef]

17. Schlesinger, J.; Daley, L.P. Applying the Chaos Theory of Careers as a Framework for College Career Centers. J. Employ. Couns. 2016, 53, 86-96. [CrossRef]

18. Krumboltz, J.D. The Happenstance Learning Theory. J. Career Assess. 2009, 17, 135-154. [CrossRef] 
19. Rhee, E.; Lee, B.H.; Kim, B.; Ha, G.; Lee, S.M. The Relationship among the Six Vocational Identity Statuses and Five Dimensions of Planned Happenstance Career Skills. J. Career Dev. 2016, 43, 368-378. [CrossRef]

20. Urbanavičiūtè, I.; Kairys, A.; Paradnikè, K.; Pociūtè, B. Capturing Serendipity in Careers: An Evaluation of the Planned Happenstance Career Inventory with Lithuanian Undergraduates. J. Career Dev. 2019, 46, 157-170. [CrossRef]

21. Ahn, S.; Jung, S.H.; Jang, S.H.; Du, X.; Lee, B.H.; Rhee, E.; Gysbers, N.; Lee, S.M. Planned happenstance skills and occupational identity status in high school students. Career Dev. Q. 2015, 63, 31-43. [CrossRef]

22. Lee, J.H.; Cho, S.; Lee, S.; Eum, W.J.; Jang, H.; Suh, S.; Lee, S.M. Initial Validation of the Planned Happenstance Career Inventory-English Version. Career Dev. Q. 2017, 65, 366-378. [CrossRef]

23. Isgor, I.Y.; Haspolat, N.K. Investigating the Psychological Well-Being and Job Satisfaction Levels in Different Occupations. Int. Educ. Stud. 2016, 9, 194-205. [CrossRef]

24. Wright, T.A.; Cropanzano, R.; Bonett, D.G. The Moderating Role of Employee Well-being on the Relationship between Job Satisfaction and Job Performance. J. Occup. Health Psychol. 2007, 12, 93-104. [CrossRef] [PubMed]

25. Dik, B.J.; O'Connor, W.F.; Shimizu, A.B.; Duffy, R.D. Personal Growth and Well-Being at Work: Contributions of Vocational Psychology. J. Career Dev. 2019, 46, 31-47. [CrossRef]

26. Diener, E. Happy People Live Longer: Subjective Well-Being Contributes to Health and Longevity. Appl. Psychol. Health Well-Being 2011, 3, 1-43. [CrossRef]

27. Seligman, M.E.P. Learned Optimism; Random House: New York, NY, USA, 1991.

28. Larson, R. Is feeling "in control" related to happiness in daily life? Psychol. Rep. 1989, 64, 775-784. [CrossRef]

29. Myers, D.G.; Diener, E. Who is happy? Psychol. Sci. 1995, 6, 10-19. [CrossRef]

30. Kim, B.; Rhee, E.; Ha, G.; Yang, J.; Lee, S.M. Tolerance of Uncertainty: Links to Happenstance. Career Decision Self-Efficacy and Career Satisfaction. Career Dev. Q. 2016, 64, 140-152. [CrossRef]

31. Burke, C.S.; Pierce, L.G.; Salas, E. Understanding Adaptability: A Prerequisite for Effective Performance within Complex Environments; Emerald Group Publishing Limited: Bingley, UK, 2006; p. 300.

32. O'Connell, D.J.; McNeely, E.; Hall, D.T. Unpacking Personal Adaptability at Work. J. Leadersh. Organ. Stud. 2008, 14, 248-259. [CrossRef]

33. Zacher, H. Career adaptability predicts subjective career success above and beyond personality traits and core self-evaluations. J. Vocat. Behav. 2014, 84, 21-30. [CrossRef]

34. Ployhart, R.E.; Bliese, P.D. Individual adaptability (I-ADAPT) theory: Conceptualizing the antecedents. consequences. and measurement of individual differences in adaptability. In Advances in Human Performance and Cognitive Engineering Research. Understanding Adaptability: A Prerequisite for Effective Performance within Complex Environments; Burke, C.S., Pierce, L.G., Salas, E., Eds.; Elsevier: Amsterdam, The Netherlands, 2006; pp. 3-39.

35. Arjanggi, R.; Kusumaningsih, L.P.S. College Adjustment of First Year Students: The Role of Social Anxiety. J. Educ. Health Community Psychol. 2016, 5, 30-39. [CrossRef]

36. Anderson, J.R.; Guan, Y.; Koc, Y. The academic adjustment scale: Measuring the adjustment of permanent resident or sojourner students. Int. J. Intercult. Relat. 2016, 54, 68-76. [CrossRef]

37. Ryff, C.D. Happiness is everything. or is it? Explorations on the meaning of psychological well-being. J. Personal. Soc. Psychol. 1989, 57, 1069-1081. [CrossRef]

38. Ryff, C.; Keyes, C. The structure of psychological well-being revisited. J. Personal. Soc. Psychol. 1995, 69, 719. [CrossRef]

39. Haider, L.J.; Hentati-Sundberg, J.; Giusti, M.; Sinare, H. The undisciplinary journey: Early-career perspectives in sustainability science. Sustain. Sci. 2018, 13, 191-204. [CrossRef] [PubMed]

40. Lang, D.J.; Wiek, A.; Wehrden, H. Bridging divides in sustainability science. Sustain. Sci. 2017, 12, 875-879. [CrossRef]

41. Vehmaa, A.; Karvinen, M.; Keskinen, M. Building a More Sustainable Society? A Case Study on the Role of Sustainable Development in the Education and Early Career of Water and Environmental Engineers. Sustainability 2018, 10, 2605. [CrossRef]

(C) 2019 by the authors. Licensee MDPI, Basel, Switzerland. This article is an open access article distributed under the terms and conditions of the Creative Commons Attribution (CC BY) license (http://creativecommons.org/licenses/by/4.0/). 